Summer 2012

\title{
Dimensions of Rights Consciousness
}

Carol J. Greenhouse

Princeton University, cgreenho@princeton.edu

Follow this and additional works at: https://www.repository.law.indiana.edu/ijgls

Part of the Constitutional Law Commons, and the International Law Commons

\section{Recommended Citation}

Greenhouse, Carol J. (2012) "Dimensions of Rights Consciousness," Indiana Journal of Global Legal Studies: Vol. 19 : Iss. 2 , Article 3.

Available at: https://www.repository.law.indiana.edu/ijgls/vol19/iss2/3

This Comment is brought to you for free and open access by the Law School Journals at Digital Repository @ Maurer Law. It has been accepted for inclusion in Indiana Journal of Global Legal Studies by an authorized editor of Digital Repository @ Maurer Law. For more information, please contact rvaughan@indiana.edu.

\section{$\Psi$}

JEROME HALL LAW LIBRARY

INDIANA UNIVERSITY

Maurer School of Law
Bloomington 


\title{
Dimensions of Rights Consciousness
}

\author{
CAROL J. GREENHOUSE*
}

\begin{abstract}
Commenting on David Engel's Article, this Comment responds particularly to Engel's formulation of horizontal and vertical axes as a metaphor for the ways different analytical approaches to law and legal consciousness potentially yield recombinant interpretive questions. Pursuing Engel's concerns with the embeddedness of local norms and social relations in state-based and global legal processes, this Comment suggests expanding the two dimensions of Engel's matrix to four, so as to highlight the relevance of social distance and temporality in the differing accounts of law he assays, and in appreciating their stakes. In so doing, this Comment situates Engel's essay as a novel and timely critical engagement with theories of the cultural relativity of law.
\end{abstract}

David Engel's writings on legal consciousness are mainstays of the socio-legal literature, illuminating some of the subtlest aspects of law's relation to personal and community life. Indeed, throughout his writings on legal consciousness, including the present Article, Engel draws attention to the nuanced ways in which law emerges in the very relation between individuals and their communities-that is, as a way of thinking, speaking, and even feeling one's connections to, or social distance from, others. ${ }^{1}$

* Arthur W. Marks '19 Professor of Anthropology and department chair at Princeton University, a specialist in the ethnography of law, and past president of the Law \& Society Association and the Association of Political and Legal Anthropologists. Other main publications include CAROL J. GREennouse, PRAYING FOR JUSTICE: FAITH, ORDER, AND COMMUNITY IN AN AMERICAN TOWN (1989); CAROL J .GREENHOUSE, A MOMENT'S NOTICE: Time Politics across Cultures (1996), Carol J. Greenhouse, The Paradox of RELEVANCE: ETHNOGRAPHY AND CITIZENSHIP IN THE UNTTED STATES (2011); CAROL J. Greenhouse, Barbara Yngvesson \& David M. Engel, LaW and Community in Three AMERICAN TOWNS (1994).

1. The themes of the present Comment are closely related to previous works of David Engel. See generally DAVID M. ENGEL \& FRANK W. MUNGER, RIGHTS OF INCLUSION: LAW AND IDENTITY IN THE LIFE STORIES OF AMERICANS wITH DISABILITIES (2003) [hereinafter RightS OF InClusion]; DAVID M. ENGEL \& JaRUWAN S. ENGEL, TORT, CUSTOMS, AND

Indiana Journal of Global Legal Studies Vol. $19 \# 2$ (Summer 2012)

(C) Indiana University Maurer School of Law 
Among Engel's contributions to the socio-legal literature are landmark works on the varied ways in which ordinary people incorporate their understandings of law into their self-understandings, as expressed in everyday narratives of experience and aspiration-as men and women, parents and partners, and neighbors and co-workers, among other relations-who are in various ways aware of having legal rights and responsibilities. ${ }^{2}$ He trains his ethnographic sights on the often-intricate connections between personal stories and law stories as he asks-literally or figuratively-how law helps, hurts, or stands apart from people's most pressing concerns. His work on legal consciousness thus probes the relevance of law beyond legal institutions, in the intimate registers of identity, personal agency, choice making, and social change. ${ }^{3}$

Engel has sustained his insights on legal consciousness through long-term ethnographic and collaborative collegial commitments in the United States and Thailand. ${ }^{4}$ As his present Article makes plain, the implications of Thai experience extend to fundamental concerns with the place of law in relation to social bonds beyond the law, and to the possibility of justice. 5 Such questions reach to the core of socio-legal studies; or perhaps it is more accurate to say these questions are the core of that interdisciplinary, interprofessional, international field. For Engel as an observer, the crucial sight line is not the conventional one that more than a century of legal sociology and anthropology might lead one to expect-across some distance between "them" and "us". Rather, just at the point where one might expect him to stage the question of

KARMA: GLOBALIZATION AND LEgal CONSCIOUSNESS IN THAILAND (2010) [hereinafter TORT, CUSTOMS, AND KARMA]; CAROL J. GREENHOUSE ET AL., LAW AND COMMUNITY IN THREE AMERICAN TOWNS (1994); David M. Engel, Globalization and the Decline of Legal Consciousness: Torts, Ghosts, and Karma in Thailand, 30 LAW \& SoC. INQUIRY 469 (2005) [hereinafter Globalization]; David M. Engel, Law, Culture, and Children with Disabilities: Educational Rights and the Construction of Difference, 1991 DuKE L.J. 166; David M. Engel, Law, Time, and Community, 21 LAW \& Soc'Y REv. 605 (1987) [hereinafter Law, Time, and Community]; David M. Engel, Origin Myths: Narratives of Authority, Resistance, Disability, and Law, 27 LAW \& Soc'Y Rev. 785 (1993); David M. Engel \& Frank W. Munger, Rights, Remembrance, and the Reconciliation of Difference, $30 \mathrm{LAW} \&$ SOC'Y REv. 7 (1996) [hereinafter Rights, Remembrance, and the Reconciliation of Difference]; David M. Engel, The Oven Bird's Song: Insiders, Outsiders, and Personal Injuries in an American Community, 18 LAW \& SOC'Y REv. 551 (1984) [hereinafter The Oven Bird's Song].

2. See generally RighTS OF INCLUSION, supra note 1; Rights, Remembrance, and the Reconciliation of Difference, supra note 1; The Oven Bird's Song, supra note 1.

3. See generally TORT, CUSTOMS, AND KARMA, supra note 1; Globalization, supra note 1.

4. See generally TORT, CUSTOMS, AND KARMA, supra note 1.

5. See David M. Engel, Vertical and Horizontal Perspectives on Rights Consciousness, 19 IND. J. GLOBAL LEGAL STUD. 423, 427-28, $432-40$ (2012). 
meaning in Thailand as an outside observer's concern, he breaks the fourth wall-this is part of the excitement of his work-and walks onto the stage himself, carrying with him some pressingly unsettled questions about the globalization of liberal law and its challenges for socio-legal scholarship. ${ }^{6}$

Instead of framing his project around cultural difference, Engel turns instead to another kind of difference. His main concern is with what is at stake in the difference between the narrative of global legal liberalism (let us call this the "liberal story") and an account of the forms of law and legal consciousness excluded by that narrative (let us call this the "diversity story"). ${ }^{7}$ In his Article, the difference between these stories is registered primarily in relation to socio-legal scholarship; however, there is also a difference in the way legal institutions operate. As Engel shows, without the liberal story, one cannot grasp how transnational legal institutions work through their jurisdictions. ${ }^{8}$ Without the diversity story, one cannot grasp how political communities work their relations to law's powers and legitimacy claims. ${ }^{9}$

As a law professor and socio-legal scholar, Engel places himself in both stories, relating the stories' different positions reflexively and critically. He draws on the device of intersecting horizontal and vertical axes to highlight the inseparability of subjectivity relative to the complexities of law lived twice-vertically, as law's object (acted upon), and horizontally, as its subject (acting upon).10 His graph, combining these axes, visualizes the possibility of relating their superficially opposed perspectives by acknowledging their respective promises and limits. He calls for a recalibration of both perspectives-each opening a place within itself for the other-for the sake of rematerializing a sense of justice around a combination of law's tangible forms, substance, and techniques, as well as intangible questions of meaning. Thus, his analysis of the liberal story relative to the diversity story is simultaneously a call for political openness in a pragmatic sense and methodological imagination in a conceptual sense. Otherwise, the axes would remain separate-the liberal story looking to individuals as adherents, and the diversity story looking to individuals through their plural engagements.

6. Id. at 440 .

7. Id. at $441-42,448$.

8. Id. at 448 .

9. Id.

10. See generally David M. Engel, Vertical and Horizontal Perspectives on Rights Consciousness, 19 IND. J. GLOBAL LEGAL STUD. 423 (2012). 
Engel's Article is profoundly relevant to the here and now. It is a compelling account of neoliberal legality and its sustaining myths, and the contemporary stakes for the future of law and society in practice and as a scholarly community. But there is also an enticing classicism to Engel's Article, and this too merits appreciation. In his implication of the justice stakes in taking vertical and horizontal perspectives on legal consciousness as separate, or as he proposes, mutually relatable and accountable, Engel's argument bears on the fundamental concept of law as a social field, and thus entails broad implications for socio-legal scholarship.

This is not the place for a comprehensive review of intellectual genealogies, so I will focus on just one theorist whose formulation of law as symbolic of social consciousness has been deeply influential on sociolegal studies. In The Division of Labor in Society, first published in 1893, Emile Durkheim 11 formulated conditions under which society could be understood as a moral community. For Durkheim, individualism derives from social participation and engagement, not the other way around. Durkheim thus rejected a notion of social contract as the basis for society, and in its place, offered the notion of collective consciousness as a rubric for the recursive effects of people's social participation on their understandings of social norms. ${ }^{12}$ This looping back is also a feature of Engel's Article. The association of society, law, and moral community was not automatic for Durkheim, as not just any collection of individuals could amount to a society in the ethical sense he wished to apply to this term. For Durkheim, mutual recognition, communication, and collaborative activity are among the conditions under which self-recognition and self-representation might emerge as individualism, but in his thesis, the idea of the individual was a function of social life, not its building block or component part. ${ }^{13}$

Thus, and this bears on Engel's Article, Durkheim sets the conditions of liberalism within society, not prior to it or apart from it. The affirmative awareness of the ethical implications of membership-

11. For critical syntheses of Durkheim's reception in the sociology of law, see ROGER COTTERRELL, EMILE DURKHEIM: LAW IN A MORAL DOMAIN (1999); EMILE DURKHEIM: JUSTICE, MORALITY, AND POLITICS (Roger Cotterrell ed., 2010). I do not mean to suggest that Durkheim is Engel's primary source or the principal source for socio-legal studies, but he is a major source for ethnographic community-based studies of law, and Engel's Article points to areas of that legacy that might yet be explored afresh.

12. ÉMILE DURKHEIM, THE DIVISION OF LABOR IN SOCIETY 233-350 (1933) [hereinafter DIVISION OF LABOR]; ÉMILE DURKHEIM, PROFESSIONAL ETHICS AND CIVIC MORALS 145-207 (1958) [hereinafter PROFESSIONAL ETHICS].

13. See DIVISION OF LABOR, supra note 12, at 173-74, 228.29; Carol Greenhouse, Durkheim and Law: Divided Readings Over Division of Labor, 7 ANN. REv. LAW \& Soc. SCI. 165, 165-85 (2011). 
"solidarity" in Durkheim's terms"14-might take various forms, but the sense of membership in a moral community is crucial to the moral or ethical bond inherent in his idea of society. ${ }^{15}$ Durkheim's writing on these points forms part of the charter for ethnographic and other community-based studies of law-in-society even today in the very connection between tradition and legal consciousness, such as in Engel's account of Thai traditions in the present Article. ${ }^{16}$

Durkheim calls the sense of membership "collective consciousness"- the phrase referring not to a group mind but to a mindfulness of membership that is symbolized by law. ${ }^{17}$ The symbolic register is key because Durkheim is not proposing that law expresses a collective conscience in some verifiable way, but rather that among law's functions is the symbolic one of making a society "visible" to itself as a collectivity. 18 Durkheim theorizes a spectrum of "types" of solidarity, anchored by "mechanical" and "organic" types-the former predicated on adherence to a group, the latter predicated on self-realization accomplished through participation in a diverse social milieu. ${ }^{19}$

In Engel's Article, the neoliberal legal order comprises a mechanical solidarity of sorts; its "constitutive outside" is akin to Durkheim's organic solidarity.' Engel's horizontal axis refers to the everyday settings where people knowingly navigate their social surroundings through personal associations with multiple communities. ${ }^{20}$ In Section III, Engel works the horizontal axis as a critical response to the limitations of the vertical axis-that is, to explain why globalization does not necessarily foster an expansion of rights consciousness even where human rights (for example) are recognized and promoted by state and local authorities. ${ }^{21}$ Human rights might expand the legal field, but this only

14. DIVISION OF LABOR, supra note 12 , at 49-229.

15. Id.

16. See generally, CotTERRELL, supra note 11; ÉMILE DURKHEIM: JUSTICE, MORALITY, AND PolitiCS, supra note 11; DIVISION OF LABOR, supra note 12; ProfEsSIONAL ETHICS, supra note 12; CAROL J. GREENHOUSE, BARBARA YNGVESSON \& DAVID M. ENGEL, LAW AND COMMUNITY IN THREE AMERICAN TOWNS 5 (1994).

17. DIVISION OF LABOR, supra note 12 , at 49.229.

18. Id. at 64 .

19. Id. at 70-132. These formulations are spelled out in The Division of Labor in Society (originally published in 1893) but also in Durkheim's other works, especially between 1888 and 1900. The modern reception of Durkheim's work on law is divided over the question of what scholars see as his communitarianism. See, e.g. Carol Greenhouse, Durkheim and Law: Divided Readings Over Division of Labor, 7 ANN. REv. L. \& Soc. SCI. 165 (2011) (discussing current scholarly debate over Durkheim's writings on law).

20. Engel, supra note 5, at 448, 454 (quoting Barbara Yngvesson, Border Politics, in The Handbook of Sociocultural ANTHRopology (James G. Carrier \& Deborah B. Gewertz eds., forthcoming 2012)).

21. Id. at $440-49$. 
highlights what Engel rightly (in my view) considers to be the fragmentary and dispersed quality of contemporary social/cultural fields. ${ }^{22}$ Rights consciousness and a resurgence of moral traditionalism are entirely consistent with Engel's account of contemporary Thailand; indeed, his analysis is suggestive of a wider state of affairs that includes the United States at the present moment. The intensity of legal cultures outside the jurisdictions of the state perhaps (paradoxically) reflects a loss of the social, as individuals are left to their own devices to find solutions to ethical dilemmas arising from injury or a sense of having been wronged. Engel shows that mechanical solidarity remains in play, so to speak-in that unchecked individualism potentially reproduces the conditions of mechanical solidarity, liberalism turned back on itself as dogmatic attachment to an idealized social order. ${ }^{23}$

With respect to contemporary neoliberalism, Engel demonstrates that the globalizing myth of liberal legalism is vulnerable at least twice: once in misreading the contingencies of its emergence as a teleology, and again in failing to take into account the contradictory nature of its transformative project. ${ }^{24}$ On the latter point, Engel argues persuasively that "the discourse of rights" does not "substitute" for tradition in Thailand, but proceeds alongside it-narrowly and at a distance..$^{25}$

This is the context in which Engel's elucidation of the vertical axis does important critical work. He associates the vertical axis with "the transnational expansion of the ideology of rights, from distant centers of neoliberal cultural production in Europe and North America through the ministries of the Thai government down to the village level"26_like a cone of light from a lamp in the dark. James Ferguson and Akhil Gupta refer to such claims to "encompassment" as a feature of modern states' "spatialization" practices-i.e., localizing practices aimed at consolidating diverse political communities into a single entity, as if political community and territory were each other's natural correlates. ${ }^{27}$ Engel reminds us that such claims should be subjected to critical ethnographic scrutiny;28 "community," in his account, is not limited to face-to-face communities. Taken together, Engel's vertical and

\footnotetext{
22. See generally Engel, supra note 10.

23. See id. at 454-55.

24. See id.

25. Id. at 440 .

26. Id. at 425 .

27. James Ferguson \& Akhil Gupta, Spatializing States: Toward an Ethnography of Neoliberal Governmentality, 29 AM. ETHNOLOGIST 981, 982 (2002).

28. See Annelise Riles, Anthropology, Human Rights, and Legal Knowledge: Culture in the Iron Cage, 108 AM. ANTHROPOLOGIST 52, 52 (2006) (explaining that singling out a characteristic and lumping people together under that characteristic ignores differences among the group).
} 
horizontal axes make vivid the unpredictably recombinant qualities of moral community, social distance, political contest, and legal authority-answering the hierarchizing practices of law-giving institutions with salutary attention to communities and their place (literally) in the circulation and consumption of law.

But here a question arises, because if we agree with Engel on this point (and I do) then we cannot assume the intersection of the vertical and horizontal axes as if this were guaranteed. I approach this question from a standpoint found in Engel's earlier work on temporality, in which he emphasizes the multiple ways in which time, life, and change are understood and selectively incorporated into legal processes. ${ }^{29}$ Drawing on that work, we may view the two axes he proposes in this Article as distinct time-space configurations around law: the horizontal axis embedded in lifetimes and communities (not necessarily localized communities) and the vertical axis embedded in official histories and managerial protocols. ${ }^{30}$ Following convention, let us call the horizontal axis the $x$-axis, and the vertical axis the $y$-axis. We might ask about the intersection of the $x$ - and $y$-axes in two ways: (1) what real-world conditions sustain their point of origin (i.e., their respective zero points)? This would not be an origin in time, but a social location where the vertical and horizontal axes are not experientially distinguishablefor example, in universities and law schools, in public sector or private sector bureaucracies, in grassroots (though not necessarily small-scale) political organizations or credit associations, and so forth; ${ }^{31}$ and, (2) what real-world conditions sustain the $(x, y)$ intersection at higher values along the axes, i.e., farther out from the point where $x=0$ and $y=0$ ? At the positions most distant from the point $(x=0, y=0)$,

29. Law, Time, and Community, supra note 1, at 606-07 (explaining how time is to be viewed separately from the relationship of law and social change).

30. See generally ANNELISE RILES, COLLATERAL KNOWLEDGE: LEGAL REASONING IN THE GLOBAL FINANCIAL MARKETS (2011).

31. See Sujatha Fernandes, Urban Soclal Movements in Chávez's Venezuela 113-59 (2010); BRUNO LATOUR, THE MAKING OF LAW: AN ETHNOGRAPHY OF THE CONSEIL D'ÉTAT (2010); BALAKRISHNAN RAJAGOPAL, INTERNATIONAL LAW FROM BELOW: DEVElopMENT, SOCIAL MOVEMENTS AND THIRD WORLD RESISTANCE 282-87 (2003); Boaventura de Sousa Santos, Beyond Neoliberal Governance: The World Social Forum as Subaltern Cosmopolitan Politics and Legality, in LAW AND GLOBALIZATION FROM BELOW: TOWARDS A COSMOPOLITAN LEGALITY 29, 29-63 (Boaventura de Sousa Santos \& César A. Rodriguez-Garavito eds., 2005); Ronen Shamir, Corporate Social Responsibility: A Case of Hegemony and Counter-Hegemony, in LAW AND GLOBALIZATION FROM BELOW: TOWARDS A COSMOPOLITAN LEGALITY 92, 92-117 (Boaventura de Sousa Santos \& César A. Rodriguez-. Garavito, eds., 2005); see generally Symposium, Bureaucracy: Ethnography of the State in Everyday Life, 34 POL. \& LEGAL ANTHROPOLOGY REV. 6 (2011). These articles are evidence of the range of conditions under which bureaucracies must struggle to maintain ideals of rationality (for better or for worse). 
presumably liberal legal ideology is strongly in force and local practice barely registers on its "radar." This, too, is a social location-for example, human rights activism on the part of indigenous women, 32 sovereignty movements premised on cultural property claims, ${ }^{33}$ International Monetary Fund and World Bank loans conditioned on structural adjustments, ${ }^{34}$ or, to choose a current example, a human rights suit brought against Greece by its hedge fund creditors. ${ }^{35}$ As one moves away from the point $(x=0, y=0)$, the asymmetries of power potentially expand to the point of each axis effectively blocking access to the other-recalling that the axes represent the interrelated effects of diverse legal discourses in actual social locations.

Thus, the motif of the graph also draws attention to the potential for a "blind spot in our knowledge"36_a conceptual void created when one axis or the other is not just omitted, but foreclosed from the other's account. This happens, for example, when political agency is occluded as a generic cultural difference-as in cultural relativist critiques of human rights tribunals' claims to universal jurisdiction. But cultural relativism in this sense of the phrase is itself limited to the void-its notion of culture stripped of political community and vitality, and pre-coded for incommensurability. Engel refers to the "exhaustion" of the universalist-relativist debate in socio-legal studies, but he does not explicitly draw attention to the richly provocative formulation of relativity he offers in place of tired relativisms. ${ }^{37}$ Relativism and relativity are not synonyms. Relativism stabilizes the observer's standpoint outside of the observed scene. Relativity, on the other hand, destabilizes the observer's standpoint, since there can be no "outside" 38 -hence the importance of breaking. down the wall between the field-as-object and the field-as-subject/discipline.

To map pathways into this zone of nonmeeting, we need two further dimensions beyond the different renderings of time-space within and beyond the neoliberal imaginary. This brings us back to Durkheim.

32. See generally AnnJanette Rosga \& Margaret L. Satterthwaite, The Trust in Indicators: Measuring Human Rights, 27 BERKELEY J. INT'L L. 253 (2009).

33. See generally JOHN L. COMAROFF \& JEAN COMAROFF, ETHNICITY, INC. 56 (2009).

34. JANET ROITMAN, FISCAL DisOBEDIENCE: AN ANTHROPOLOGY OF ECONOMIC REgULATION IN CENTRAL AFRICA 4 n.6 (2005).

35. Landon Thomas Jr., Hedge Funds May Sue Greece if It Tries to Force Losses, N.Y. TTMES, Jan. 18, 2012, http://www.nytimes.com/2012/01/19/business/global/hedge-funds-maysue-greece-if-it-tries-to-force-loss.html?_r=2\&scp=2\&sq=greece\%20hedge\%20funds\&st=cse.

36. See RAlPH Ellison, Shadow AND ACT 311 (special ed. 1994).

37. Engel, supra note 5 , at 441 .

38. Id. at 455 (quoting Barbara Yngvesson, Border Politics, in THE HaNDBook of Sociocultural ANThropology (James G. Carrier \& Deborah B. Gewertz eds., forthcoming 2012)). 
Durkheim named "volume" and "density" (i.e., scale and role density) as the drivers of organic solidarity. ${ }^{39}$ In Durkheim's thinking, expanding the number of social roles (volume) as well as any individual's roles (density) increases the likelihood that the conditions of organic solidarity will be met in an enduring way. Fulfilling those conditions would mean that the recognition and articulation of diverse normative repertoires is an everyday occurrence. The dynamic quality of the terms in Durkheim's usage is suggestive of Albert Einstein's later formulation of relativity around the dimensions of time, space, volume, and velocity-though Einstein was explicit in refusing any analogy to social life. ${ }^{40}$ Still, these additional terms underscore the difference between a perspectival relativism (two dimensions) and the relativity of experience (four dimensions). Relativism draws theoretical possibility comparatively, between systems; relativity draws theoretical possibility into the very midst of experience - as relateability. Accordingly, Engel's relativity brings us back to fundamentals in an exciting and productive way.

For socio-legal scholars engaged with globalization, the theoretical import of Engel's analysis of the limitations of a liberal discourse of rights is at least three-fold. First, the discourse of legal liberalism represented by Engel's vertical dimension is not fully assimilable to the knowledge(s) or experience(s) associated with the heterogeneous legal cultures and normative communities that comprise the horizontal dimension. Cultural relativity is profoundly important to Engel's concept of legal consciousness, but cultural relativism fails (for reasons he elucidates throughout) as a challenge to legal liberalism because it is encompassed within its discourse, pre-coded for erasure.

Second, in drawing our attention from either axis to the relationship between them, Engel productively moves away from prevalent concerns with the production of law and its (putative) uptake, toward the circulation and consumption of legal ideas as constitutive social relations in themselves. This shift of focus is illuminating, particularly in correcting the mythic "universalism" of human rights law as a bestowal of the global north upon the global south. In place of those

39. DIVISION OF LABOR, supra note 12 , at 152, 233-82.

40. See Albert Einstein, The Meaning of Relativity (2005); Albert Einstein, Relativity: THE Special and THE General Theory (2006); Albert Einstein, SIDELIGHTS ON RELATIVITY (1922). Einstein's refusal to extend (by application or metaphor) his theory of relativity to social relations was part of his break with Henri Bergson. See Suzanne Guerlac, Thinking IN TIME: AN INTRODUCTION To HenRI BERGSON (2006). 
myths, the demand for human rights together with their formulations can be situated more diversely in relation to social movements. ${ }^{41}$

Third, by considering each of his two axes as intersecting arrangements of social connections and distances, Engel productively and provocatively forecloses the possibility of an external observer's position. This highlights the alienation intrinsic to the liberal narrative, as well as new possibilities of engagement and discovery. Indeed, merging the subject and object of socio-legal studies is a ringing keynote of his essay-a compelling appeal that takes us back to our intellectual foundations and quickens what is best and most enduring in our shared craft.

41. See generally JeAN COMAROFF \& John L. COMAROFF, TheORY OF THE SOUTH: OR, How EuRo-America is Evolving TOWARD AFrica (2012); SAMUEl MOYN, The LAST UTOPIA: HUMAN RIGHTS IN HISTORY (2010). 